\title{
A digital volumetric tomography (DVT) study in the mandibular molar region for miniscrew placement during mixed dentition
}

\author{
Mayur S. Bhattad¹, Sudhindra Baliga², Pavan Vibhute ${ }^{3}$
}

DOI: $h$ ttp://dx.doi.org/10.1590/2176-9451.20.2.055-060.oar

Objective: To assess bone thickness for miniscrew placement in the mandible during mixed dentition by using digital volumetric tomograph (DVT). Material and methods: A total of 15 healthy patients aged 8-10 years old, with early exfoliated mandibular second deciduous molar, were included. DVT images of one quadrant of the mandible were obtained using Kodak extraoral imaging systems and analyzed by Kodak dental imaging software. The error of the method (EM) was calculated using Dahlberg's formula. Mean and standard deviation were calculated at 6 and $8 \mathrm{~mm}$ from the cementoenamel junction (CEJ).Paired t-test was used to analyze the measurements. Results: Buccal cortical bone thickness, mesiodistal width and buccolingual bone depth at $6 \mathrm{~mm}$ were found to be $1.73+0.41,2.15+0.49$ and $13.18+1.22$ $\mathrm{mm}$, respectively; while at $8 \mathrm{~mm}$ measurements were $2.42+0.34,2.48+0.33$ and $13.65+1.25 \mathrm{~mm}$, respectively. EM for buccal cortical bone thickness, mesiodistal width and buccolingual bone depth was $0.58,0.40$ and 0.48 , respectively. The difference in measurement at 6 and $8 \mathrm{~mm}$ for buccal cortical plate thickness $(\mathrm{P}<0.05)$ and buccolingual bone thickness $(\mathrm{P}<0.05)$ was found to be significant, whereas for mesiodistal width it was insignificant $(\mathrm{P}>0.05)$. Conclusion: Bone thickness measurement has shown promising evidence for safe placement of miniscrews in the mandible during mixed dentition. The use of miniscrew is the best alternative, even in younger patients.

Keywords: Miniscrews. Digital volumetric tomograph. Inter-radicular bone. Cortical bone.

Objetivo: avaliar, por meio de tomografia volumétrica digital (TVD), a espessura óssea necessária para a instalação de mini-implante na arcada inferior durante a fase de dentição mista. Métodos: um total de 15 pacientes saudáveis, com idades entre 8 e 10 anos, com segundo molar inferior decíduo irrompido recentemente, foram incluídos no presente estudo. Imagens de TVD da hemiarcada inferior foram obtidas utilizando sistemas de imagens extrabucais Kodak. As imagens foram analisadas por meio do programa de imagens Kodak. O erro do método (EM) foi calculado utilizando a fórmula de Dahlberg. Médias e desvios-padrão foram calculados de $6 \mathrm{a} 8 \mathrm{~mm}$ aquém da junção amelocementária. $\mathrm{O}$ teste $t$ foi utilizado para a análise das medidas. Resultados: a espessura do osso cortical vestibular, largura mesiodistal e profundidade óssea vestibulolingual, a $6 \mathrm{~mm}$, foram de $1,73+0,41 ; 2,15+0,49 ;$ e $13,18+1,22 \mathrm{~mm}$, respectivamente. Já a $8 \mathrm{~mm}$, os valores foram de 2,42 + 0,34; 2,48 + 0,33; e 13,65 $+1,25 \mathrm{~mm}$. O EM para a espessura do osso cortical vestibular, largura mesiodistal e profundidade óssea vestibulolingual foi de $0,58,0,40$ e $0,48 \mathrm{~mm}$, respectivamente. A diferença entre as medidas a 6 e $8 \mathrm{~mm}$ para a espessura do osso cortical vestibular $(\mathrm{p}<0,05)$ e a espessura óssea vestibulolingual $(\mathrm{p}<0,05)$ foi significativa, embora não tenha sido significativa para a largura mesiodistal $(\mathrm{p}<0,05)$. Conclusão: a mensuração da espessura óssea demonstra evidências promissoras para a segura instalação de mini-implantes na arcada inferior e na fase de dentição mista. O uso de mini-implantes tem se mostrado a melhor alternativa, mesmo nos casos de pacientes mais jovens.

Palavras-chave: Mini-implantes. Tomografia volumétrica digital. Osso interradicular. Osso cortical.

» The authors report no commercial, proprietary or financial interest in the products or companies described in this article.

» Patients displayed in this article previously approved the use of their facial and intraoral photographs.

${ }^{1}$ Senior lecturer, Sharad Pawar Dental College and Hospital, Department of Pedodontics and Preventive Dentistry, Sawangi, Wardha, Maharashtra, India. ${ }^{2}$ Professor, Sharad Pawar Dental College and Hospital, Department of Pedodontics and Preventive Dentistry, Sawangi, Wardha, Maharashtra, India. ${ }^{3}$ Associate professor, Sharad Pawar Dental College and Hospital, Department of Orthodontics, Sawangi, Wardha, Maharashtra, India.
How to cite this article: Bhattad MS, Baliga S, Vibhute P. A digital volumetric tomography (DVT) study in the mandibular molar region for miniscrew placement during mixed dentition. Dental Press J Orthod. 2015 Mar-Apr;20(2):55-60. DOI: http://dx.doi.org/10.1590/2176-9451.20.2.055-060.oar

Submitted: January 21, 2014 - Revised and accepted: October 13, 2014

Contact address: Mayur S Bhattad

Department of Pedodontics and Preventive Dentistry

HSRSSM Dental College and Hospital

Hingoli, Maharashtra, India - Ph. No. 09860273039

Email: mayur_b99@yahoo.co.in 


\section{INTRODUCTION}

Maintenance of arch length during the primary, mixed and permanent dentition is of great significance for the normal development of future occlusion because premature loss of primary teeth due to caries, trauma, ectopic eruption, or other causes may lead to undesirable tooth movements of primary and/ or permanent teeth including loss of arch length. ${ }^{1}$ Space management is a key responsibility of dental practitioners who are concerned about monitoring the developing dentition, as the loss of arch length may lead to problems, such as crowding, dental impaction, crossbite formation, and dental midline discrepancies. $^{2}$ The use of space maintainers/retainers are advocated to maintain or regain lost arch length and may potentially obviate the need for later extractions and/or complex orthodontic treatment, hence space management continues to play a vital role in Dentistry. ${ }^{3}$ However, these space maintaining devices in routine practice have shown appreciable adverse effects, such as plaque accumulation, dental caries, dislodged or broken appliances, interference with successor eruption, undesirable tooth movement and soft tissue impingement. ${ }^{2,45}$

In recent years, a new treatment method using miniscrews has been developed and applied to clinical orthodontic treatment. This technique enabled tooth movement that was impossible with conventional orthodontic treatment and served as an alternative method

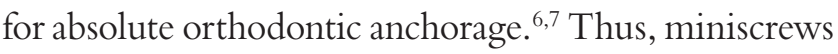
may have the potential to aid comprehensive space management and to overcome the disadvantages of conventional space maintaining devices.

Miniscrews offer the advantages of lower cost, smaller size, easy surgical placement/removal procedure, no additional laboratory work and minimum waiting period for osseointegration. ${ }^{7,8}$ Numerous anatomic sites for miniscrew placement have been proven in adults; however, very few data are available for the mixed dentition age group. ${ }^{6}$ The scope of miniscrews in Pediatric Dentistry for space maintenance and as an anchorage device in the late mixed dentition period may be possible and needs to be evaluated. Hence, this study aimed to assess the mesiodistal bone width, buccal cortical plate thickness and buccolingual bone thickness in the posterior region of the mandible for placement of miniscrews during mixed dentition.

\section{MATERIAL AND METHODS}

The study protocol was approved by DMIMS, Sawangi, Wardha, Mahrashtra state, India Institutional Review Board and an informed consent form was signed by parents/guardians accompanying the patients prior to the digital volumetric tomographic (DVT) scan. A total of 15 healthy patients, aged 8-10 years old, with early or recently exfoliated mandibular second deciduous molar and 2-4 mm bone covering erupting mandibular second premolar were included in the study. Patients with severe facial or dental asymmetries, systemic diseases or bone abnormalities, significant medical or dental history, vertical or horizontal periodontal bone loss were excluded. ${ }^{6,9,10}$

Digital volumetric tomographic images of one quadrant of the mandible in all 15 patients were obtained using Kodak 9000 extraoral imaging system. Either the right or left quadrant of the mandible was randomly chosen for measurement taking, as it was previously proven that there were no differences in cortical bone thickness between sides of the jaws. ${ }^{11,12}$

\section{DATA ANALYSIS}

The images obtained were analyzed by Kodak dental imaging software (3D module V 2.2). At the time of measurements, scanned images were oriented in all three planes: sagittal, axial and coronal. In the posterior interradicular areas of the mandible, the sagittal slice was used to locate the inter-radicular area of interest for measurements (Fig 1). The vertical reference plane was made parallel to the long axes of the roots, and the horizontal reference plane was marked along the cementoenamel junction (CEJ) of permanent mandibular first $\operatorname{molar}^{10}$ (Fig 2). Measurements were carried out at 6 and $8 \mathrm{~mm}$ apical to the cementoenamel junction. Mesiodistal bone width in the mandibular first molar region was measured in sagittal slice (Fig 3) whereas the thickness of the buccal cortical plate (Fig 4) and buccolingual bone thickness or depth was measured in the areas between the second premolar and first molar in the coronal slice (Fig 5).

\section{STATISTICAL ANALYSIS}

Data obtained for measurements at $6 \mathrm{~mm}$ and 8 $\mathrm{mm}$ were statistically analyzed by means of paired ttest. The scanned images were measured by the same observer after a two week interval. The error of the method (EM) calculations were carried out by means of Dahlberg's formula. ${ }^{6}$ 


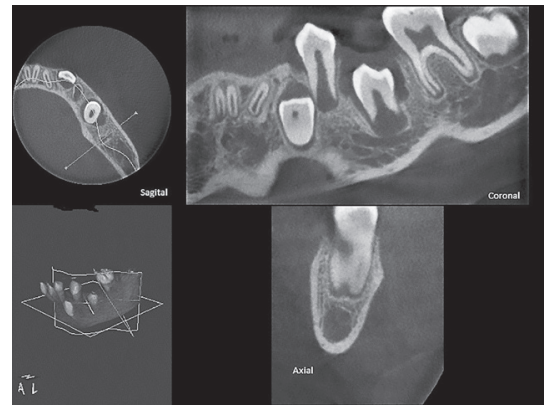

Figure 1 - Sagittal, coronal and axial slices.

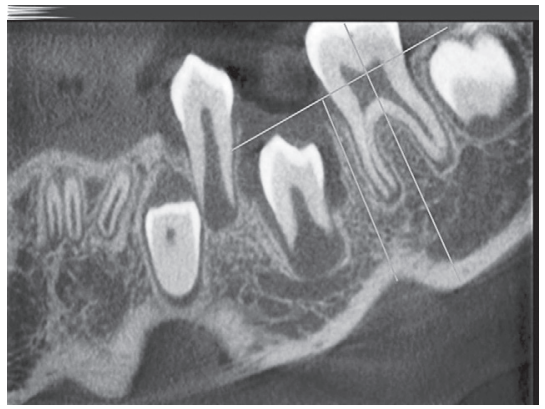

Figure 2 - Vertical and horizontal reference plane.

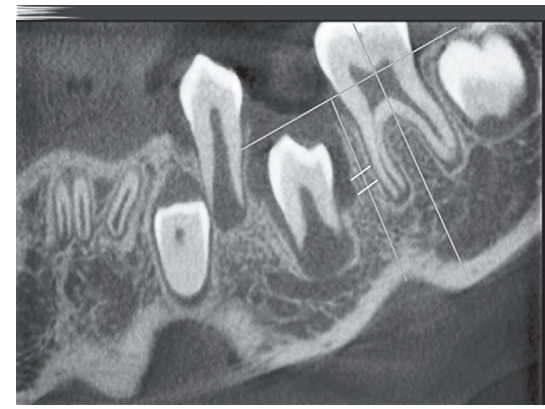

Figure 3 - Mesiodistal bone width at 6 and $8 \mathrm{~mm}$

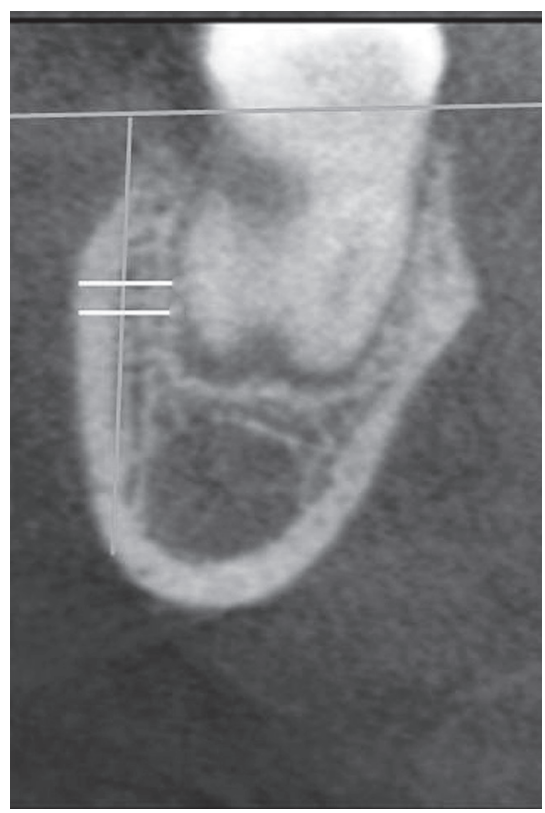

Figure 4 - Buccal cortical bone thickness at $6 \mathrm{~mm}$ and $8 \mathrm{~mm}$.

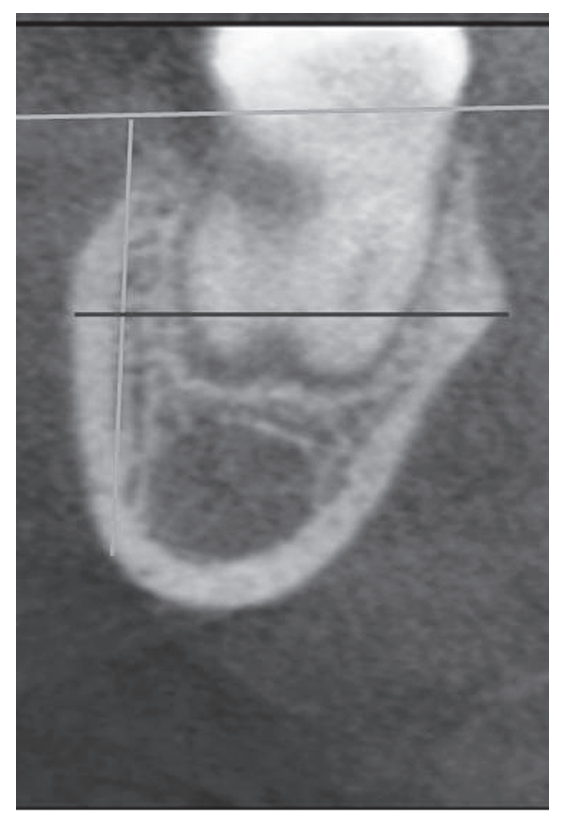

Figure 5 - Buccolingual bone depth at $6 \mathrm{~mm}$ and $8 \mathrm{~mm}$.

\section{RESULTS}

Of the 15 images obtained, three were discarded due to poor image quality. Mean and standard deviation for each of the variables were calculated. Mesiodistal bone width measurements at $6 \mathrm{~mm}$ and $8 \mathrm{~mm}$ ranged from 1.3 to $2.9 \mathrm{~mm}$. Results for buccal cortical plate thickness and buccolingual bone depth ranged between $1.5-2.9 \mathrm{~mm}$ and $11.9-15.4 \mathrm{~mm}$, respectively. Mean values for mesiodistal bone width, buccal cortical plate thickness and buccolingual bone depth at $8 \mathrm{~mm}$ were found to be sufficient for miniscrews placement with a diameter of $1.2-1.4 \mathrm{~mm}$ and length of $10-14 \mathrm{~mm}$ (Table 1).

Differences in measurement at 6 and $8 \mathrm{~mm}$ for buccal cortical plate thickness $(\mathrm{P}<0.05)$ and buccolingual bone thickness $(\mathrm{P}<0.05)$ were found to be

significant, whereas for mesiodistal width it was insignificant $(\mathrm{P}>0.05)$ (Table 2). The error of the method (EM) for mesiodistal bone width, buccal and palatal cortical plate thickness and buccopalatal bone depth measurements were found to be $0.40,0.58$ and 0.48 , respectively (Table 3).

\section{DISCUSSION}

Miniscrews ${ }^{13-17}$ are now frequently used for establishing absolute anchorage for orthodontic tooth movement. They are easily inserted and removed without a mucoperiosteal flap, and can be loaded immediately after insertion. ${ }^{18}$ Their potential applications include improving anchorage, increasing the horizontal component of force applied during space closure, posterior 
Table 1 - Mean and standard deviation for mesiodistal bone width, buccal cortical plate thickness and buccolingual bone depth measurements.

\begin{tabular}{|c|c|c|c|c|c|c|}
\hline \multirow{2}{*}{ Patient } & \multicolumn{2}{|c|}{ Mesiodistal width } & \multicolumn{2}{|c|}{ Buccal cortical plate } & \multicolumn{2}{|c|}{ Buccolingual bone thickness } \\
\hline & $6 \mathrm{~mm}$ & $8 \mathrm{~mm}$ & $6 \mathrm{~mm}$ & $8 \mathrm{~mm}$ & $6 \mathrm{~mm}$ & $8 \mathrm{~mm}$ \\
\hline 1 & $2.3 \mathrm{~mm}$ & $2.6 \mathrm{~mm}$ & $2.0 \mathrm{~mm}$ & $2.9 \mathrm{~mm}$ & $13.1 \mathrm{~mm}$ & $13.7 \mathrm{~mm}$ \\
\hline 2 & $2.7 \mathrm{~mm}$ & $2.6 \mathrm{~mm}$ & $1.5 \mathrm{~mm}$ & $2.6 \mathrm{~mm}$ & 11.9 mm & $12.1 \mathrm{~mm}$ \\
\hline 3 & $1.3 \mathrm{~mm}$ & $2.2 \mathrm{~mm}$ & $1.9 \mathrm{~mm}$ & $1.9 \mathrm{~mm}$ & $15.4 \mathrm{~mm}$ & $15.4 \mathrm{~mm}$ \\
\hline 4 & $2.3 \mathrm{~mm}$ & $2.8 \mathrm{~mm}$ & $1.8 \mathrm{~mm}$ & $2.4 \mathrm{~mm}$ & $12.4 \mathrm{~mm}$ & $12.8 \mathrm{~mm}$ \\
\hline 5 & $2.4 \mathrm{~mm}$ & $2.9 \mathrm{~mm}$ & $2.1 \mathrm{~mm}$ & $2.5 \mathrm{~mm}$ & $13.5 \mathrm{~mm}$ & $14.8 \mathrm{~mm}$ \\
\hline 6 & $1.9 \mathrm{~mm}$ & $2.6 \mathrm{~mm}$ & $1.9 \mathrm{~mm}$ & $2.2 \mathrm{~mm}$ & $12.8 \mathrm{~mm}$ & $13.1 \mathrm{~mm}$ \\
\hline 7 & $2.0 \mathrm{~mm}$ & $2.8 \mathrm{~mm}$ & $1.8 \mathrm{~mm}$ & $2.6 \mathrm{~mm}$ & $13.4 \mathrm{~mm}$ & $15.1 \mathrm{~mm}$ \\
\hline 8 & $2.1 \mathrm{~mm}$ & $2.7 \mathrm{~mm}$ & $2.2 \mathrm{~mm}$ & $2.7 \mathrm{~mm}$ & $13.6 \mathrm{~mm}$ & $14.3 \mathrm{~mm}$ \\
\hline 9 & $1.9 \mathrm{~mm}$ & $2.4 \mathrm{~mm}$ & $1.9 \mathrm{~mm}$ & $2.5 \mathrm{~mm}$ & 13.4 mm & $13.7 \mathrm{~mm}$ \\
\hline 10 & $2.4 \mathrm{~mm}$ & $2.8 \mathrm{~mm}$ & $1.8 \mathrm{~mm}$ & $2.3 \mathrm{~mm}$ & $13.1 \mathrm{~mm}$ & $13.5 \mathrm{~mm}$ \\
\hline 11 & $2.3 \mathrm{~mm}$ & $2.5 \mathrm{~mm}$ & $2.0 \mathrm{~mm}$ & $2.0 \mathrm{~mm}$ & $12.9 \mathrm{~mm}$ & $12.5 \mathrm{~mm}$ \\
\hline 12 & $2.2 \mathrm{~mm}$ & $2.5 \mathrm{~mm}$ & $1.5 \mathrm{~mm}$ & $2.4 \mathrm{~mm}$ & $12.7 \mathrm{~mm}$ & $12.8 \mathrm{~mm}$ \\
\hline Mean \pm SD & $2.15 \pm 0.49$ & $2.48 \pm 0.33$ & $1.73 \pm 0.41$ & $2.42 \pm 0.34$ & $13.18 \pm 1.22$ & $13.65 \pm 1.25$ \\
\hline
\end{tabular}

Table 2 - Paired t-test for mesiodistal bone width, buccal and palatal cortical plate thickness and buccolingual bone depth measurements

\begin{tabular}{cccc}
\hline & Mesiodistal width & Buccal cortical plate thickness \\
T-test value & 1.76 & 3.37 \\
Pvalue & 0.13 (N.S., P $>0.05)$ & $0.021($ Sig, P $<0.05)$ & Buccolingual depth \\
\hline
\end{tabular}

Table 3 - Error of the method for mesiodistal bone width, buccal and palatal cortical plate thickness and buccolingual bone depth measurements at 6 and 8 mm.

\begin{tabular}{ccc}
\hline & Mesiodistal width & Buccal cortical plate thickness \\
Error of the method & 0.40 & 0.58 \\
\hline
\end{tabular}

intrusion in open-bite cases, distalization of molars, extrusion of impacted teeth, molar uprighting and correction of midline diastema. ${ }^{7,8,18}$

The mandibular buccal region had the thickest cortical bone of all evaluated regions. Thicker cortical bone has been previously reported in the mandible than in the maxilla. ${ }^{12,19}$ Increased cortical bone thickness and higher bone mineral density have been shown in the mandibular buccal region when compared to the maxillary buccal and lingual regions, ${ }^{20-23}$ as the mandible is found to be always under torsional and bending strains or forces, whereas the maxilla is generally subjected to more compressive forces. ${ }^{24}$ Also, in animal experiments, it has been demonstrated that regions which experience higher strain during function develop thicker cortical bones. ${ }^{25}$

Thus, in humans, cortical bone in the mandibular buccal region was found to be thicker posteriorly, and it becomes progressively thinner anteriorly. ${ }^{12,26}$ This pattern might also be explained by the higher functional demands placed on posterior teeth. Van Eijden ${ }^{24}$ reported an increase in the longitudinal elastic modulus (increase in stress per unit of strain) between the molar region and the symphysis. Stress and strain differences could give rise to the differences in cortical thickness in this region.

Age-related differences between younger, adolescent and older patients in cortical bone thickness might be explained by changes in functional capacity, because maximum bite forces, masticatory muscle size, and muscle activity have the tendency to increase with age. Changes in the functional capacity, which alter biomechanical stresses and strains, have shown to manipulate cortical bone thickness and bone density because increased strains and stresses within a certain limit increase cortical bone thickness and bone mineral density. ${ }^{10}$

In the mandible, the safest sites for miniscrew insertion have been found to be between the first and second molars, first and second premolars, first 
molar and first premolar and first premolar and canine. These sites provide moderate inter-radicular space and sufficient cortical plate thickness. However, due to root proximity, the area suitable for miniscrew insertion is over $8 \mathrm{~mm}$ from the alveolar crest. ${ }^{6}$

In this study, the CEJ was selected as the starting point for measurements, as compared to other studies in which alveolar crest was used, which could be affected by different periodontal problems..$^{27,28}$ The maximum level of measurement in this study was selected to be 6 and $8 \mathrm{~mm}$ from CEJ because miniscrew placement is most commonly advised in the area of attached gingiva. ${ }^{29}$

The selection of proper miniscrew diameter and length is important as it may hamper eruption or deflect erupting premolars during mixed dentition. Hence, selection will depend upon inter-radicular mesiodistal bone width, buccal cortical plate thickness and buccolingual bone depth. ${ }^{28}$ Currently, most miniscrews have diameters ranging from 1.2 to $2 \mathrm{~mm}$. Presently, there are no relative data available on the amount of bone that is to be present between miniscrews and dental roots for both periodontal health and miniscrew stability. Considering that the width of the periodontal ligament is approximately $0.25 \mathrm{~mm}$, it is assumed that a minimum clearance of $1 \mathrm{~mm}$ of alveolar bone around the screw could be sufficient for periodontal health. ${ }^{6,28}$ Combining this value with our data, the safe zone for a miniscrew $1.2 \mathrm{~mm}$ in diameter, placed in the inter-radicular spaces have been identified to be at $8 \mathrm{~mm}$.

Radiographic analysis is a pre-requirement in determining anatomic sites for implant placement. Three-dimensional imaging techniques, such as CT or MRI imaging, have turned into important diagnostic imaging in the head and neck. ${ }^{30} \mathrm{CT}$ involves a considerably higher radiation dose $^{31}$ in comparison to conventional radiography, as well as high working costs and considerable investment in equipment. ${ }^{32}$
Digital volume tomograph (DVT) is a new imaging technique which produces three-dimensional images similar to $\mathrm{CT}$, but at a low radiation dose which is comparable with panoramic radiograph, and at a lesser cost. DVT technology in clinical practice has numerous advantages, such as image accuracy, rapid scan time and display modes which are unique to maxillofacial imaging. Three-dimensional volumetric tomograph is also well suited for imaging the craniofacial area because it provides clear images of highly contrasted structures which are extremely useful for evaluating bone. ${ }^{33,34}$ Hence, in this study, three-dimensional digital volumetric tomograph (DVT) was used to assess mesiodistal bone width, cortical bone thickness and buccolingual bone depth.

In the mandibular molar region, mini-implants placement between premolars is not recommended due to the presence of mental foramen..$^{29}$ Hence, the proximity of the mental foramina and bone density in the posterior region needs to be assessed in mixed dentition in order to provide a three-dimensional analysis for miniscrew placement. However, the results of the present study need to be correlated with clinical assessment so as to maintain optimum periodontal health and miniscrew stability.

\section{CONCLUSION}

After evaluating the amount of bone thickness in the inter-radicular spaces of the mandibular posterior region, the results of the present study show promising evidence for safe miniscrews placement in the mixed dentition period. This results need to be reevaluated in a larger scale.

Miniscrew has proved to be the best alternative to routinely use clinical appliances for space management, uprighting and distalization of molars, and intrusion and extrusion of teeth. It can also be used as a temporary prosthesis abutment in younger patients. 


\section{REFERENCES}

1. Guidelines on the use of space maintainers following premature loss of primary teeth. J Can Dent Assoc. 1997;63(10):753-66

2. Laing E, Ashley P, Naini FB, Gill DS. Space maintenance. Int J Paediatr Dent 2009;19(3):155-62.

3. Ngan P, Randy GA, Fields JRH. Management of space problems in the primary and mixed dentitions. J Am Dent Assoc, 1999;130:1330-9.

4. Dincer M, Haydar S, Unsal B, Turk TS. Space maintainer effects on intercanine arch width and length. J Clin Pediatr Dent. 1996;21(1):47-50.

5. Cuoghi OA, Bertoz FA, de Mendonca MR, Santos EC. Loss of space and dental arch length after the loss of the lower first primary molar: A longitudinal study. J Clin Pediatr Dent 1998:22(2):117-20

6. Paola MP, Cristina I, Sefano V, Aldo C. Safe Zones: a guide for miniscrew positioning in the maxillary and mandibular arch. Angle Orthod. 2006:76(2):191-7.

7. Carano A, Velo S, Leone P, Siciliani G. Clinical applications of the Miniscrew Anchorage System. J Clin Orthod. 2005:39(1):9-24

8. Mark R, Yanosky, Holmes JD. Mini-implant temporary anchorage devices: orthodontic applications. Compend. 2008;29(1):12-20.

9. Kim SH, Yoon HG. Evaluation of interdental space of the maxillary posterior area for orthodontic mini-implants with cone-beam computed tomography. Am J Orthod Dentofacial Orthop. 2009;135(5):635-41.

10. Farnsworth D, Rossouw PE, Ceen RF, Buschangd PH. Cortical bone thickness at common miniscrew implant placement sites. Am J Orthod Dentofacial Orthop. 2011:139(4):495-503.

11. Kang S, Lee SJ, Ahn SJ, Heo MS, Kim TW. Bone thickness of the palate for orthodontic mini-implant anchorage in adults. Am J Orthod Dentofacial Orthop. 2007:131(4 Suppl):S74-81.

12. Schwartz $\mathrm{CL}$, Dechow PC. Variations in cortical material properties throughout the human dentate mandible. Am J Phys Anthropol. 2003:120(3):252-77.

13. Costa A, Raffainl M, Melsen B. Miniscrews as orthodontic anchorage: a preliminary report. Int J Adult Orthodon Orthognath Surg. 1998;13(3):201-9.

14. Kanomi R. Mini-implant for orthodontic anchorage. J Clin Orthod. 1997:31:763-7.

15. Park HS, Bae SM, Kyung HM, Sung JH. Micro-implant anchorage for treatment of skeletal Class I bialveolar protrusion. J Clin Orthod. 2001;35(7):417-22.

16. Paik $\mathrm{CH}$, Woo YJ, Boyd R. Treatment of an adult patient with vertical maxillary excess using miniscrew fixation. J Clin Orthod. 2003;37(8):423-8.

17. Xun $\mathrm{CL}$, Zeng $\mathrm{XL}$, Wang $X$. Clinical application of miniscrew implant for maximum anchorage treatment. Chin J Stomatol. 2004;39:505-8.

18. Fortini A, Cacciafesta V. Sfondrini MF, Cambi S, Lupoli M. Clinical applications and efficiency of miniscrews for extradental anchorage. Orthodontics. 2004;1(2):1-12

19. Peterson J, Wang Q, Dechow PC. Material properties of the dentate maxilla. Anat Rec A Discov Mol Cell Evol Biol. 2006:288(9):962-72.
20. Ono A, Motoyoshi M, Shimizu N. Cortical bone thickness in the buccal posterior region for orthodontic mini-implants. Int J Oral Maxillofac Surg 2008;37(4):334-40

21. Deguchi T, Nasu M, Murakami K, Yabuuchi T, Kamioka H, Takano-Yamamoto T. Quantitative evaluation of cortical bone thickness with computed tomographic scanning for orthodontic implants. Am J Orthod Dentofacial Orthop. 2006;129(6):721.e7-12

22. Park HS, Lee YJ, Jeong SH, Kwon TG. Density of the alveolar and basal bones of the maxilla and the mandible. Am J Orthod Dentofacial Orthop. 2008;133(1):30-7.

23. Mitsuru M. Clinical indices for orthodontic mini-implants. J Oral Sci. 2011:3(4):407-12

24. Van Eijden TM. Biomechanics of the mandible. Crit Rev Oral Biol Med. 2000;11(1):123-36

25. Daegling DJ, Hylander WL. Experimental observation, theoretical models, and biomechanical inference in the study of mandibular form. Am J Phys Anthropol. 2000;112(4):541-51.

26. Katranji A, Misch K. Wang HL. Cortical bone thickness in dentate and edentulous human cadavers. J Periodontol. 2007:78(5):874-8.

27. Fayed MM, Pazera P, Katsaros C. Optimal sites for orthodontic mini-implant placement assessed by cone beam computed tomography. Angle Orthod 2010;80(5):939-51

28. Monnerat C, Restle L, Mucha JN. Tomographic mapping of mandibular interradicular spaces for placement of orthodontic mini-implants. Am J Orthod Dentofacial Orthop. 2009;135(4):428.e1-9; discussion 428-9.

29. Melsen B. Mini-implants: where are we? J Clin Orthod 2005;39:539-47.

30. Fuhrmann R, Klein HM, Wehrbein H, GuË nther RW, Dietrich P. Hochauo Ė sende computertomographie fazialer und oraler knochendehiszenzen. Dtsch ZahnaĖrztl Z. 1993:48:242-6

31. Hassfeld S, Streib S, Stahl H, Stratmann U, Fehrentz D, ZoĖ ller J. Low-dosecomputertomographie des kieferknochens in derpra Ė implantologischen Diagnostik. Mund Kiefer Gesichts Chir. 1998:2:188-93.

32. Arai Y, Tammisalo E, Iwai K, Hashimoto K, Shinoda K. Development of a compact computed tomographic apparatus for dental use. Dentomaxillofac Radiol. 1999:28(4):245-8.

33. Ziegler CM, Woertche R, Brief J, Hassfeld S. Clinical indications for digital volume tomography in oral and maxillofacial surgery. Dentomaxillofac Radiol. 2002;31(2):126-30

34. Scarfe WC, Farman AG, Sukovic P. Clinical applications of cone-beam computed tomography in dental practice. J Can Dent Assoc. 2006;72(1):75-80. 